\title{
Violence of Rhetoric: Silencing the Tongue in Kyd and Shakespeare
}

Jennifer Flaherty

Christophe Hausermann (ed.)

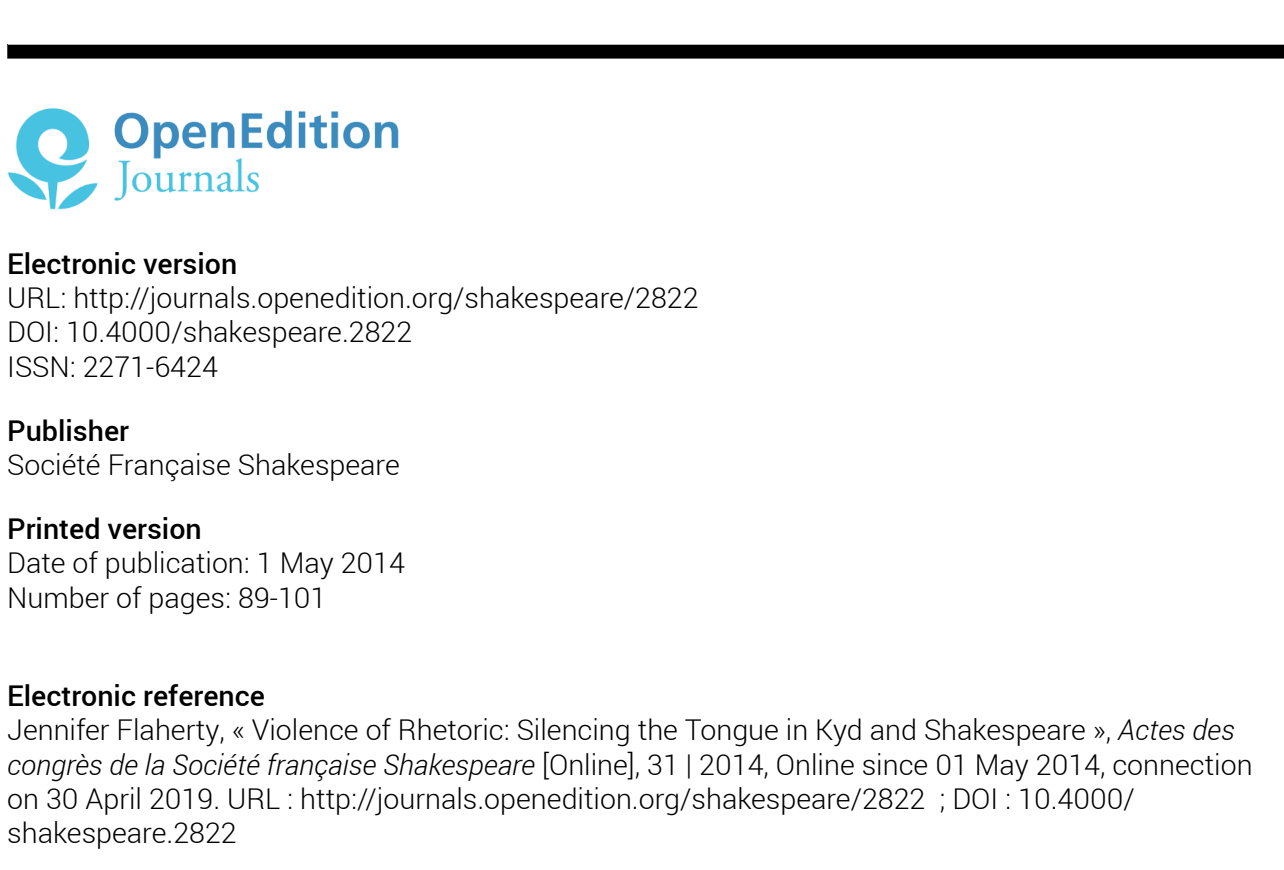




\title{
Violence of RHETORIC: SilenCing THE TONGUE IN KYD AND SHAKESPEARE
}

\author{
Jennifer FLAHERTY
}

Using Kyd's The Spanish Tragedy and Shakespeare's Titus Andronicus, my paper explores the rhetorical significance of tongue mutilation in early modern drama. These revenge tragedies prominently feature scenes in which characters lose the power of speech when their tongues are cut out. While revenge tragedies abound with messy death and mutilation scenes, I argue that the mutilation of the tongue has a power that extends beyond the spectacle of violence. As the organ that produces speech, the tongue is a means of communication, subversion, and manipulation. Violence against the tongue functions as a form of violence against language itself.

Au travers des pièces The Spanish Tragedy de Thomas Kyd et Titus Andronicus de Shakespeare, cet article explore la signification rhétorique de la mutilation de la langue dans le théâtre élisabéthain. Ces tragédies de la vengeance contiennent de nombreuses scènes dans lesquelles les personnages sont réduits au silence après qu'on leur a coupé la langue. Bien que ces pièces abondent en meurtres sordides et en scènes de mutilation, nous montrerons que la mutilation de la langue a une force qui va au-delà du spectacle de la violence. Organe de la parole, la langue est un moyen de communication, de subversion et de manipulation. La violence exercée sur cet organe constitue une forme de violence contre le langage même.

$\mathrm{I}$

n Kyd's The Spanish Tragedy and Shakespeare's Titus Andronicus, mutilation of the tongue can be devastating or liberating depending on how speech and rhetoric are perceived by the characters. In Kyd's Spanish Tragedy, language is portrayed as inherently deceptive, betraying even the speaker. Speech is a confusing liability or dangerously misleading rather than a source of power and agency. Hieronimo's self-mutilation is a bold act of resistance, and the destruction of the tongue is a source of empowerment rather than suffering. Shakespeare, by contrast, presents the tongue as a powerful member; the loss of speech and language is a loss of agency and control. Tongue mutilation is gendered; it is a violation linked to rape in the cases of female characters such as Lavinia. My paper considers the power of language and the connections between the destruction of the tongue and the destruction caused by the tongue - the rhetoric of violence and the violence of rhetoric.

Although the theme La Langue de Shakespeare suggests an exploration of Shakespeare's language, my interest lies in the way that Shakespeare and his contemporary Thomas Kyd use the tongue itself in their revenge tragedies Titus Andronicus and The Spanish Tragedy. Revenge tragedies are replete with messy scenes of death and dismemberment. The mutilation of the tongue, however, has a power that extends beyond the spectacle of violence. As the organ that produces 
speech, the tongue is a means of communication, subversion, and manipulation. Violence against the tongue functions as a form of violence against language itself, and tongue mutilation serves as an argument about speech, speaking, and personal agency. Hieronimo's removal of his own tongue in Kyd's The Spanish Tragedy suggests that language is inherently deceptive, betraying even the speaker. Shakespeare's Titus Andronicus, by contrast, demonstrates the violation inherent in the loss of speech when Demetrius and Chiron remove Lavinia's tongue after raping her. In both plays, the tongue is a powerful weapon that can be used for truth or falsehood, and the mutilation of the tongue is an attempt to control information by destroying the means of producing speech.

In The Spanish Tragedy, Kyd undercuts the connection between the tongue and true communication. While the tongue has the power of speech, it is an untrustworthy power that often works against the speaker as well as the listener. Kyd emphasizes the unreliability of the tongue, as well as the difficulty of controlling it. Words are described as "trifling," meaningless when compared to "valiancy" or "golden coin." Effective communication between two individuals is difficult at best in the first acts of the play, and it breaks down completely by the final act. Appropriately, the action of the play culminates with a play within the play in which each character delivers his or her lines in a different "tongue," which keeps the characters from understanding each other's speeches and the audience from fully grasping the plot of the play. During this play Hieronimo and Bel-Imperia finally step forward as revengers, killing those who wronged them in a stunning spectacle of violence and miscommunication that mirrors The Spanish Tragedy itself. Hallett and Hallett argue that a revenger's play-within-a-play "must be a reflection of his mental state." ${ }^{2}$ The lingual confusion, verbal anxiety, and violence of the play-within-a-play all demonstrate Hieronimo's mindset, and these ideas extend from the smaller spectacle throughout the rest of the play.

In the very first speech of the play, the ghost of Andrea states that he "saw more sights than thousand tongues can tell"3 during his journey

1 Kyd, The Spanish Tragedy in English Renaissance Drama: A Norton Anthology, ed. David Bevington, New York, Norton, 2002, II.i.19, 45, 53.

2 Charles A. Hallett and Elaine S. Hallett, The Revenger's Madness: A Study of Revenge Tragedy Motifs, Lincoln, University of Nebraska Press, 1980, p. 90.

3 Kyd, op. cit., I.i.57. 
into Hades. Stated in the middle of an eighty-five-line speech in which Andrea relates what he has seen and done since his death, this line negates the validity of all the lines surrounding it and questions the very practice of relating personal experiences. The tongues of the living have no more power than the tongues of the dead, and the characters struggle with the impossibility of conveying both facts and emotion through speech. When Bel-Imperia begs Horatio to relate the story of Andrea's death, he believes he is giving an accurate account, and she accepts his answer as truth, when the true story is one of betrayal and ambush rather than a heroic battle. In The Spanish Tragedy, stories -even "true" stories - are often incomplete, and emotions run too deep to be accurately conveyed in speech. Descriptions fail, grief cannot be effectively expressed, and the central character destroys his own tongue in an effort to remain silent. After learning who is responsible for Horatio's death, Hieronimo says: "my grief, my heart, my thoughts no tongue can tell."4 Faced with the depth of Hieronimo's suffering, the tongue is unequal to the task of adequately conveying his emotion. Later, when Hieronimo describes himself as "the hopeless father of a hapless son, whose tongue is tun'd to tell his latest tale," he shows rather than tells the death of his son by exposing Horatio's body. In The Spanish Tragedy, the tales of tongues are inadequate, and characters who know secrets are silenced by murder or imprisonment before they can use their tongues to any purpose. Any attempt to use speech as a powerful weapon against others is thwarted. Serberine and Pendringano, who have enough knowledge of Lorenzo's actions to be a threat to him, are effectively eliminated before they fully realize the power they have.

The characters who ascribe the most power to language are Lorenzo and Castile, and they do so out of fear that their evil deeds will be revealed through speech. Lorenzo states that it is beyond his power "to stop the vulgar liberal of their tongues," 5 and he warns Castile that "a small advantage makes a water-breach." ${ }^{6}$ His lines acknowledge that a few whispers can gain enough momentum to become a great force, and he admits that rumors are out of his sphere of control. Castile worries that "a scandal were't among the kings, to hear Hieronimo exclaim on

4 Ibid., III.ii.67.

5 Ibid., III.xiv. 74

6 Ibid., III.xiv.75. 
thee!"7 But Hieronimo gives them little cause for their paranoia, showing no inclination to use the power of the many-tongued multitude to influence politics and bring about justice. The fears of the villains are dispelled almost as soon as they are voiced when Hieronimo abandons his suit to the king, opting to pursue violent revenge rather than legal recompense. While unfounded, the concerns expressed by Castile and Lorenzo depict an anxiety about the power of speech. Their desire (and inability) to control the speech of their victims, their accusers, and the general public adds to the characterization of the tongue as an unpredictable and potentially dangerous member.

Their anxiety over the tongue becomes gendered when the play addresses the speech and power of Bel-Imperia, suggesting a link between a woman's "two mouths" in relation to the gender and sexuality of the tongue. Peter Stallybrass and David Kastan explain this connection as "the dominant phantasy of the body's topography upon the Jacobean stage: the phantasy of the gendered mouth. The mouth: a gaping hole, and absence through which presence is formed and dissolved." ${ }^{8}$ In The Spanish Tragedy, Bel-Imperia is presented as a woman who speaks with confidence and proudly controls her own body. She chooses two men to become her lovers and loudly refuses another, despite the political implications of rejecting Balthazar. Lorenzo maintains that by murdering Horatio and cloistering Bel-Imperia away to "stop her mouth" he will be able "save [her] honor and [his] own."10 He attempts to control both her body and her voice, keeping her contained sexually until her marriage with the appropriate Bathazar and keeping her from verbally revealing his involvement in Horatio's death. Bel-Imperia, who manages to warn Hieronimo, does not do so through speech, since her brother is successful in his attempts to "stop her mouth;" 11 she is forced, instead, to communicate in writing, using her own blood as ink. Katharine Maus asserts that sexually active women in revenge tragedies exacerbate the male anxiety "over the possession of women defined as the passive objects of male transactions." 12 If chaste

\footnotetext{
7 Ibid., III.xiv.60-70.

8 Peter Stallybrass and David Scott Kastan, Staging the Renaissance, New York, Routledge, 1991, p. 219.

9 Kyd, op. cit., II.iv.63.

10 Ibid., III.x.38

11 Ibid., II.iv.63.

12 Katharine Eisaman Maus, ed, Four Revenge Tragedies, New York, Oxford, 1995, p. xviii.
} 
female characters in revenge tragedies are often 'controlled' through sexual and oral violations, ${ }^{13}$ the women who take control of their own sexuality are doubly intimidating to the male characters because their power is not only carnal - it is verbal.

If Bel-Imperia demonstrates the threat of feminine sexual and verbal power, Hieronimo's growing concerns about controlling his own tongue reveal a different sort of anxiety. While Lorenzo's imprisonment of Bel-Imperia suggests a patriarchal desire to control her voice and body, Hieronimo's anxiety is focused instead on self-control. He begins the play with a reputation as an excellent advocate and judge, as demonstrated by the line "there's not any advocate in Spain that can prevail, or will take half the pain, that he will in the pursuit of equity"14 and by Lorenzo and Castile's fears of possible legal suits he might make against them. But Hieronimo shows no signs of being a strong rhetorician; he rather seems to fear and distrust language. Besides his brief stint as a corregidor, which ends when he destroys the bonds of his clients, the only demonstration of Hieronimo's rhetorical ability to influence the king is his unsuccessful venture that his "tongue should plead for young Horatio's right"15 in the first act. When both Lorenzo and Horatio claim Balthazar as their prisoner, Hieronimo argues that the reward belongs to Horatio, who fought and defeated Balthazar, rather than Lorenzo, whom he compares to a hare who tries to "pull dead lions by the beard." 16 Although the king answers his suit by telling him that "for thy sake thy son shall want no right," ${ }^{17}$ the division of the spoils corresponds more to the summary presented by Balthazar than to Hieronimo's assessment of the case. Hieronimo disparages Lorenzo's role in the capture, but the king chooses to reward both parties. As Hallett and Hallett state, Hieronimo "cuts a poor figure as a judge" and "his occupation makes little sense if we try to view it realistically." 18

In the early speeches of Hieronimo and Andrea, the tongue is identified as an imperfect tool. By the end of the play, Hieronimo establishes the tongue as a liability that is more dangerous to Hieronimo himself than to any of his enemies. Fearful that his plans will be

13 For example, Lavinia in Titus Andronicus and Gloriana in The Revenger's Tragedy.

14 Kyd, op. cit., III.viii.52-5.

15 Ibid., I.iv. 169

16 Ibid., I.iv. 172.

17 Ibid., I.iv. 174.

18 Hallett and Hallett, The Revenger's Madness, p. 133. 
discovered by those around him, Hieronimo advises himself to "enjoin [...] thy tongue to milder speeches than thy spirit affords." 19 For Hieronimo, the tongue is not the loyal servant of the mind, but an unruly subject who needs to be kept in check. Although he mentions that he also needs to maintain control over his eyes, heart, hands, and knees in order to secure his revenge, his tongue remains the organ which is most unreliable and dangerous to him. In the same scene in which he reminds himself to keep his words in check, Hieronimo loses control of both his mind and his speech, revealing his thoughts by railing on the murder of his son. Hieronimo's preoccupation with controlling his own tongue ties into the warnings expressed by Desiderius Erasmus in his treatise Lingua (1525), which links excessive speech with femininity. As Patricia Parker explains, "the diseases of this 'wanton' bodily member are illustrated primarily by the excesses of the tongues of men. And yet throughout, the quality itself - excess of speech or overabundance of language - is repeatedly coded as womanish or feminine." ${ }^{20}$ Hieronimo fears the excesses of his own tongue, which he views as a feminizing weakness. Instead of taking pride in eloquence and using words to his advantage, he rejects language (and his own tongue) in favor of violent action.

Hieronimo's anxiety about his own tongue is most evident in the final act, when, even after giving a seventy-five line speech that outlines his motives, he is still worried that he will reveal too much. He finishes his speech by asking his horrified audience to "urge no more words; I have no more to say,"21 and the physical violence of the play-within-aplay gives way to verbal violence as the king, Castile, and the viceroy try to take control of Hieronimo's tongue. Despite the fact that Hieronimo has already made his motives clear, the three grief stricken men cry "Speak, traitor! Damn bloody murderer, speak!" 22 and "I'll make thee tell." ${ }^{3}$ Threatened with "tortures" and not trusting his unstable tongue to hold in his secrets in the face of torture when he has once before betrayed his thoughts in a moment of madness, Hieronimo bites out his own tongue. Hieronimo's self-mutilation has little to do with a desire for

19 Kyd, op. cit., III.viii.41.

20 Parker, quoted in Nathalie Vienne-Guerrin, The Unruly Tongue in Early Modern England: Three Treatises, Plymouth, Fairleigh Dickinson University Press, 2012, p. xxi.

$21 \mathrm{Kyd}$, op. cit., IV.iv.151-2

22 Ibid., IV.iv. 163.

23 Ibid., IV.iv.184. 
suffering; it is a bold act of resistance, which the King recognizes when he cries "he has bitten forth his tongue rather than reveal what we required!" 24 In a play in which speech is a hindrance rather than a help and one's own tongue cannot be trusted, Hieronimo embraces a bloody, defiant silence before finally ending his own life.

Kyd's play systematically strips away the tongue's power. Speeches are inaccurate, and descriptions are inadequate. The destruction of the tongue is an act of empowerment rather than punishment, ensuring freedom from a body part which is seen as decidedly untrustworthy. Titus Andronicus, however, re-establishes the tongue as a powerful tool. Where Hieronimo, the just revenger, trembles in fear of his own tongue in Kyd's play, the many villains of Shakespeare's revenge tragedy are concerned only with the tongues of their enemies. A tongue can inflict a significant amount of pain in Titus Andronicus, whether by ordering an execution, breaking a vow, or simply by telling the truth. Shakespeare elevates the functions of rhetoric in his revenge tragedy, emphasizing the power of persuasion, and therefore increasing the value of the tongue. Although the mutilation of the tongue is as central to the plot of Titus Andronicus as it is to The Spanish Tragedy, the loss of a tongue is heart-breaking rather than liberating for Shakespeare's characters.

The first character to speak the word "tongue" in Titus Andronicus is Chiron, Tamora's son, as he debates with his brother Demetrius over which of them loves Lavinia (another man's wife) more. Chiron jeeringly answers his brother's threats by calling him a "foulspoken coward, that thunder'st with thy tongue,/And with thy weapon nothing darest perform!" 25 Chiron draws a distinction between words and action, and his taunt is emasculating. R. de Maulde La Claviere cites a Renaissance proverb: "the tongue is feminine, the arm is masculine."26 The tongue is also feminized in the Renaissance play Lingua, in which the tongue admits that she is of the "feeble sex" 27 and is thoroughly defeated when she challenges the masculine personifications of the five senses for superiority. If Demetrius uses words, he is using the feminine

24 Ibid., VI.iv.194-5.

25 William Shakespeare, Titus Andronicus, ed. Jonathan Bate, London, Arden, 1995, II.i.58-9.

26 R. de Maulde La Claviere, Women of the Renaissance: A Study in Feminism, ed. George Herbert Ely, Whitefish, Kessinger Publishing, 2003, p. 317.

27 "Lingua or the Combat of the Tongue and the Five Senses for Superiority." The Ancient British Drama: Volume Second, ed. Robert Dudley, London, William Miller, 1810, p. 214 
weapon of the tongue rather than the more masculine choice of a sword. Chiron's taunt dismisses verbal power as easily as Hieronimo does in Kyd's play. This is not The Spanish Tragedy, however; by the time Chiron speaks these words at the beginning of the second act, the audience has already seen that words have a great deal of power in Titus Andronicus, and that a tongue is no idle weapon. Titus' words to the people bring Saturninus to power, and, as Emperor, Saturninus' words are law. With a single line, he sets Tamora and her sons free, and with two more he raises her to the status of empress. Words put Titus out of favor and bring him back again in the same scene, which he acknowledges, thanking Tamora for her suit by stating that "these words, these looks infuse new life in me." ${ }^{28}$ In a play in which speech can bring about such dramatic changes, threats and slanders should not be taken as lightly as Chiron takes them here.

It is Aaron, a shrewder observer than Chiron, who recognizes the power of the tongue in this scene. He quells the argument quickly, citing the danger of publicly fighting for the love of a woman who is already married to the emperor's brother. To Aaron, the tongue is a formidable opponent, capable of winning a battle and ruining a life without the benefit of physical strength. While he admits no fear of any man in the play, Aaron calls for caution in the emperor's court, describing it as a "house of Fame... full of tongues, of eyes, and ears." 29 By establishing the need for prudence and safety, Aaron is able to turn the boys from the public arena of the court to the "ruthless, dreadful, deaf and dull"3o environment of the woods. Just as easily, he is then able to twist the love the boys have for Lavinia into a violent, destructive lust. He is their tutor in ruthlessness and caution, teaching them not only to fear the tongue, but to silence it permanently when necessary. Aaron is a warrior who respects both the tongue and the sword, reconciling the conflict established by Chiron's earlier statement.

The power of speech in Titus Andronicus is not limited to the dangers of rumor and accusation. If the tongue is a female organ, then it is fitting that the play should showcase a woman for her rhetorical talent. Tamora demonstrates confidence in her own powers of persuasion, and she carefully crafts a reputation for an ability to bend others to her will.

28 William Shakespeare, op. cit., I.i.466

29 Ibid., II.i. 128 .

30 Ibid., II.i.129. 
She illustrates her power by persuading Saturninus to pardon each of the Andronichi in turn, and she maintains her position as voice in Saturninus' ear throughout the play. She even assures Titus that she will appeal on behalf of his sons, which sets up the chain of events that leads to the loss of Titus' hand. Again, issues of sexuality run parallel to acts of speech, and Tamora's verbal power over Saturninus is just as corrupting as her sexual behavior, while her machinations lead to the death of the entire ruling family. The anxiety over Bel-Imperia's sexuality in The Spanish Tragedy pales beside the implications of Tamora's infidelity in Titus Andronicus. Any child Tamora conceives as the wife of the Emperor is legally in line to inherit the throne, and Tamora's tryst with Aaron, resulting in a dark-skinned child, is evidence of how her abuse of sexual and rhetorical power is destructive to Rome. There are moments, however, when Tamora seems to overestimate, or at least overstate, her abilities. Although she has a great deal of sway over Saturninus, she has very little control over Titus, as evidenced by her attempt to persuade him to approach Lucius on behalf of Saturninus. She confidently tells Saturninus:

$$
\begin{aligned}
& \text { If Tamora entreat him then he will, } \\
& \text { For I can smooth and fill his aged ears } \\
& \text { With golden promises that, were his heart } \\
& \text { Almost impregnable, his old ears deaf } \\
& \text { Yet should both ear and heart obey my tongue. }{ }^{31}
\end{aligned}
$$

By this point in the play, she has traded any credibility she ever had with Titus for his lost hand, which he willingly gave up to redeem his sons after her promise to argue for them. It is possible that she understands this for, despite her speech to Saturninus, she does not "entreat him" as Tamora. Instead, she dresses herself as Revenge, and even promises to deliver "some violent death" 32 to Tamora and her sons. Moreover, she does not appeal to his powers of reasoning with "golden promises" or even "plead to him" 33 to change Lucius' mind about the attack, as she told Saturninus she would. She caters instead to his madness, trying to trick him with fantasies and, ironically, is tricked by him into turning her two remaining sons over to the man who has murdered her first son. When glorifying her own powers of persuasion regarding Titus, Tamora

31 Ibid., IV.iv.94-8

32 Ibid., v.ii. 108

33 Ibid., IV.iv.112. 
fails to recall that her tongue could not save her eldest son from death as a ritual sacrifice, despite the eloquence of her pleas.

While words as threats, commands, and accusations have a great deal of power in Titus Andronicus, pleas for mercy have hardly any effect. The tongue, which can launch armies and order executions, does very little to move hearts. In the first act, Tamora appeals to Titus' sense of honor, imploring him to "stain not thy tomb with blood" and to "draw near the nature of the gods... in being merciful,"34 but her son is executed despite her supplication. Beginning with that execution, the characters in the play are firm in the face of extreme suffering. By the third act, it is apparent to both the audience and Titus that to ask for mercy in Rome is as futile as telling one's "sorrows to the stones." 35 What little apparent mercy is given, such as the pardon of the Andronichi in the first act and the promise to release Titus' sons in exchange for his hand, is revealed as lies and empty promises. It is no surprise when Lavinia's entreaty to Tamora to grant her "present death [...] and one thing more that womanhood denies my tongue to tell" ${ }^{36}$ goes unheeded. This plea comes at the turning point in the play, as the character of the revenger shifts from Tamora to Titus. In a striking reversal, this scene provides Tamora a measure of revenge for her unanswered pleas in the first act. In the earlier scene, Tamora had pled in vain for her son's life; here, Lavinia pleads in vain for her own death.

Lavinia's lines themselves are heavy with significance. Not only is Lavinia not allowed to preserve her chastity and avoid a fate worse than her "tongue can tell," but her tongue is actually rendered incapable of telling anything, including what has been done to her. She begs Tamora for death, but she receives it (at the hands of her own father, not Tamora) long after she is able to plead for anything. In the play where a tongue has enough power to end a man's life but not enough power to spark sympathy in his heart, even pleas for death are mocked, and Lavinia is dragged off the stage to endure the violation she fears most. When Lavinia appears again, she enters the stage "her hands cut off and her tongue cut out, and ravished." 37 Through the characters of Tamora and Lavinia, Shakespeare demonstrates a link between the two female

34 Ibid., I.i.119-121.

35 Ibid., III.i.36.

36 Ibid., II.ii.173-4.

37 Ibid., II.iv.1. 
mouths, much as Kyd does through Bel-Imperia. Tamora's excessive rhetoric is linked with her sexuality, and she is presented as destructive rather than productive. Lavinia claims the right to choose her own husband rather than bow to the will of her father or her emperor, just as Bel-Imperia defies Lorenzo when she refuses Balthazar. She is then silenced, taking on the role of Philomela that Aaron ascribes to her. Like the mythological character, Lavinia is violated twice: both sexually and orally, and the combined injuries are equally responsible for destroying her agency.

Although the removal of a tongue in order to prevent speech would certainly have reminded audiences of Hieronimo's selfmutilation in The Spanish Tragedy, there is a sharp contrast between the two acts of violence. Hieronimo's action is one of rebellion, illustrating his defiant agency in opposing those who are trying to force him to reveal information. Lavinia experiences the converse situation nearly all of her agency is stripped away by her rape and mutilation. In The Spanish Tragedy, the court is aghast when Hieronimo bites out his tongue in an effort to keep his secrets, while Lavinia is ridiculed with the secret information that she has no way to reveal when Demetrius mockingly instructs her to "go tell, and if thy tongue could speak, who 'twas that cut thy tongue and ravished thee." 38 While Hieronimo is freed by the loss of a tongue that could betray his thoughts and ruin his plans for justice, Lavinia's tongue is cut out to rob her of the means to achieve justice. By removing her tongue and denying her the power of speech, Demetrius and Chiron not only prevent her from revealing their identities, they also deny her "the opportunity...of explicitly requesting or consenting to her own death at the hands of her father." 39 Hieronimo, by contrast is still able to complete his final act of liberty: suicide. Instead of being liberating, Lavinia's mutilation is a violation.

Both Titus Andronicus and The Spanish Tragedy play with the many associations of the word "tongue;" they offer profound interpretations of what it means to speak or persuade, then reduce the tongue to just another body part to lose in the name of revenge. The tongue can be a weapon, a tool, a bribe, or a dangerous liability, and the mutilation of a tongue can be devastating or liberating. In both plays,

38 Ibid., II.iv.1-2

39 Margaret E. Owens, Stages of Dismemberment, Newark, University of Delaware Press, 2005, p. 106. 
the characters who die tongueless are victims of those in power rather than villains. For Hieronimo and Lavinia, the mutilations that they undergo are performed in order to ensure that the characters lack speech, with the motives in both cases being a desire to conceal information. In these revenge tragedies, however, the truth always comes out at the end, despite the characters who want to silence it. The Spanish court learns enough about Hieronimo's motives to make his final gesture seem futile, and Lavinia finds a way to name her rapists even without her tongue. It is easy to link the tongue to truth, since all of the attempts to stop a character's tongue are also attempts to hide the truth. For both Kyd and Shakespeare, however, the relationship between speech and truth is much more complex, and any attempt to silence the truth by silencing the tongue is destined to fail. Truth transcends the tongue, bringing events to light despite any attempts to drown them in blood. 


\section{BIBLIOGRAPHY}

Kyd, Thomas, The Spanish Tragedy, in English Renaissance Drama: A Norton Anthology, ed. David Bevington, New York, Norton, 2002. de Maulde La Claviere, R., Women of the Renaissance: A Study in Feminism (reprint of text from 1900), ed. George Herbert Ely, Whitefish, Kessinger Publishing, 2003.

Eisaman Maus, Katharine, ed., Four Revenge Tragedies, New York, Oxford, 1995.

Hallett, Charles A. and Elaine S. Hallett, The Revenger's Madness: A Study of Revenge Tragedy Motifs, Lincoln, University of Nebraska Press, 1980.

Owens, Margaret E., Stages of Dismemberment, Newark, University of Delaware Press, 2005

Stallybrass, Peter and David Scott Kastan, Staging the Renaissance, New York, Routledge Press, 1991.

Shakespeare, William, Titus Andronicus, ed. Jonathan Bate, London, Arden, 1995.

Vienne-Guerrin, Nathalie, The Unruly Tongue in Early Modern

England: Three Treatises, Plymouth, Fairleigh Dickinson University Press, 2012. 